\title{
Threat of allergenic airborne grass pollen in Szczecin, NW Poland: the dynamics of pollen seasons, effect of meteorological variables and air pollution
}

\author{
Małgorzata Puc
}

Received: 25 June 2010/Accepted: 28 October 2010/Published online: 12 November 2010

(C) The Author(s) 2010. This article is published with open access at Springerlink.com

\begin{abstract}
The dynamics of Poaceae pollen season, in particularly that of the Secale genus, in Szczecin (western Poland) 2004-2008 was analysed to establish a relationship between the meteorological variables, air pollution and the pollen count of the taxa studied. Consecutive phases during the pollen season were defined for each taxon $(1,2.5,5,25,50,75,95$, $97.5,99 \%$ of annual total), and duration of the season was determined using the $98 \%$ method. On the basis of this analysis, the temporary differences in the dynamics of the seasons were most evident for Secale in 2005 and 2006 with the longest main pollen season (90\% total pollen). The pollen season of Poaceae started the earliest in 2007, when thermal conditions were the most favourable. Correlation analysis with meteorological factors demonstrated that the relative humidity, mean and maximum air temperature, and rainfall were the factors influencing the average daily pollen concentrations in the atmosphere; also, the presence of air pollutants such as ozone, $\mathrm{PM}_{10}$ and $\mathrm{SO}_{2}$ was statistically related to the pollen count in the air. However, multiple regression models explained little part of the total variance. Atmospheric pollution induces aggravation of symptoms of grass pollen allergy.
\end{abstract}

M. Puc ( $₫)$

Department of Botany and Nature Conservation,

University of Szczecin, Felczaka 3c,

71-412 Szczecin, Poland

e-mail:mapuc@univ.szczecin.pl
Keywords Poaceae $\cdot$ Secale $\cdot$ Seasonal dynamics . Meteorological variables $\cdot$ Air pollution $\cdot$ Poland

\section{Introduction}

The grass family is one of the largest among the flowering plants. Representatives of the Poaceae are found in almost every habitat. Grass pollen is the major cause of pollinosis in many parts of the world. The number and species of airborne pollen vary according to the time of day, seasonal and weather conditions, geographical location and proximity to pollen sources. The distance from grass pollen source is important especially for sufferers of allergic diseases; for instance, measurement of rye pollen count carried out by Rapiejko et al. (2004) on a field of blooming ray revealed a concentration of over $7,300 \mathrm{p} / \mathrm{m}^{3}$ of air at $1.8 \mathrm{~m}$ above ground level and about $200 \mathrm{p} / \mathrm{m}^{3}$ at $0.5 \mathrm{~km}$ away from the field borders. For persons with grass pollen allergy, this means a hazard of acute allergic symptoms including dyspnoea (difficult or laboured respiration).

Aerobiological studies providing data on exposure to allergens in the air are of substantial importance for the pollen allergy diagnosis. The most important agent causing pollinosis in Europe is grass pollen. Approximate estimations indicate that in Europe, $3-5 \%$ of the population, i.e. 15 million people, suffer from pollinosis during the flowering season of 
Poaceae (Obtułowicz 2001). The pollen season of grass in Northern, Central and Eastern Europe lasts from the beginning of May to the end of July; in the Southern Europe-from April to June (D'Amato 1991; D'Amato et al. 2007). However, in Poland, Poaceae pollen can linger on in the air longer, to the second half of September (Szczepanek 1994; Kasprzyk and Walanus 2010).

The pollen of Lolium (ryegrass, darnel), Phleum (timothy), Dactylis (orchard grass) and Arrhenaterum (oat grass) has strong allergenic properties. The most important antigen from among the cereals is Secale cereale (ryegrass); with very few exceptions, all grass pollen types show a very high degree of crossreactivity (the reaction between an antibody and an antigen that differs from the immunogen, mainly proteins). Grass pollen can also cross-react with food like beans, peas, cereals, peanut and fruit (melon, watermelon) as well as edible vegetables (carrot, celery) (Reindl et al. 2000; Andersson and Lindholm 2003; Asero et al. 2003). The majority grass species are allogenic, producing large amounts of pollen. The taxa of the Poaceae family with high allergenic potency are characterized with particularly high pollen productivity. For instance, the pollen production per anther/inflorescence in Arrhenatherum album reaches 8,720-19,760/about 5 million; in Lolium rigidum 6,870-14,860/above 5 million; in Dactylis glomerata 1,740-3620/about 8 million; in Festuca arundinacea 6,090-12,390/about 12 million (Prieto-Baenapablo et al. 2003); and in Secale cereale 19,000/4.2 million (De Vries 1971).

Literature gives a few references to the number of pollen grains needed to provoke an allergic reaction in susceptible individuals. The grass pollen concentration at which clinical allergic symptoms can develop depends also on individual reactivity and show regional differentiations. In Poland, the people sensitive to Poaceae pollen developed the first disease symptoms when exposed to more than 20 grains $/ \mathrm{m}^{3}$ (Rapiejko et al. 2004). In Turku (Finland), a count of less than 30 grass pollen grains $/ \mathrm{m}^{3}$ was significantly correlated with respiratory tract symptoms at the start of the Poaceae pollen season (Rantio-Lehtimaki et al. 1991). In London (UK), the lowest concentration of grass pollen able to induce the appearance of hayfever symptoms was shown to be $10-50$ grains $/ \mathrm{m}^{3}$ (Davies and Smith 1973). In Croatia, the threshold value amounts to 30 grains $/ \mathrm{m}^{3}$ (Peternel et al. 2006), and in Spain, the first allergy symptoms were observed at 25 grains $/ \mathrm{m}^{3}$ (Rodriguez-Rajo et al. 2003).

Increasing concentrations of atmospheric pollutants i.e. ozone, sulphur dioxide, nitrogen oxides and particulate matter (PM) in industrialized regions and urban complexes intensify the risk of allergies. The subjects living in urban areas tend to be more affected by plant-derived respiratory disorders than those who live in rural areas. Separate effects of bioaerosols and PM as well as their synergistic effects can aggravate respiratory allergy and other pulmonary diseases (D'Amato 2000; Parnia et al. 2002; Adhikari et al. 2006; Jianan et al., 2007). Ozone has an irritating effect on the airways' mucous membrane. It is formed as a result of complex photochemical reactions between the volatile organic substances, nitrogen oxides and sunlight. These reactions are particularly intense in the air over big cities in summer, after the morning rush hour. D'Amato (2000), Riediker et al. (2001), Parnia et al. (2002) and Wilson et al. (2004) have proved a sensitizing effect of ozone in people suffering from asthma of allergic origin. Masuch et al. (1997), studying the allergy-inducing properties of Lolium perenne, have shown that the presence of ozone increases the concentration of the allergen Lol p 5 in the pollen grains of this grass. Schöene et al. (2004) have found that ozone stress is responsible for the disrupted development of pollen in L. perenne. In the presence of ozone, the number of pollen grains of perennial ryegrass containing amyloplasts decreases and vacuolization of the grains with amyloplasts is stronger. Sulphur dioxide is formed as a result of combustion of high sulphur-content coal. Nitrogen oxides come mainly from exhaust gases, especially diesel exhausts and gas cookers. These compounds can damage the mucous membrane of the respiratory tract, causing an increase in the mucus viscosity. They have also been found to occur on the surface of pollen grains (Śpiewak et al. 1996; Yanagisawa et al. 2006). Air pollution can also directly affect pollen grains as the pollen grains exposed to polluted air have been found to contain a reduced amount of allergens in the cells. Moreover, the exposure of pollen grains to a mixture of pollutants $\left(\mathrm{CO}_{2}, \mathrm{NO}_{2}, \mathrm{SO}_{2}\right)$ has resulted in a greater decrease in the content of allergens than the exposure to only one type of pollutant (Rogerieux et al. 2007). However, pollen of Phleum pratense (timothy grass) collected at roadsides showed 
significantly reduced allergen release in comparison with pollen collected with rural meadows (Behrend and Becker 2001).

The aim of this work was to analyse the dynamics of the grass pollen season Poaceae family, in particular the Secale genus, over a period of five years and check a relationship between meteorological factors, air pollution and the concentrations of Poaceae pollen in the atmosphere of Szczecin, Poland.

\section{Materials and methods}

\subsection{Site information}

The city of Szczecin is situated in the north-west Poland. The climate of the city is shaped by morphological diversity of the surrounding area, the presence of watercourses and lakes along with large forest complexes at the peripheries. The average annual temperature for the years $1956-1990$ is $8.4^{\circ} \mathrm{C}$, January is the coldest month $\left(-1.1^{\circ} \mathrm{C}\right)$ and July-the hottest $\left(17.7^{\circ} \mathrm{C}\right)$. Annual mean relative humidity ranges between 70 and $77 \%$, and rainfall is mainly concentrated in summer. Mean annual precipitation is $528 \mathrm{~mm}$. The daily precipitates of over $20 \mathrm{~mm}$ or draught periods lasting longer than 20 days are rare. The average month wind speed over the years $1956-1990$ is $3.6 \mathrm{~m} / \mathrm{s}$. The climate of the region is modified by the influence of Atlantic air masses and the proximity of the Baltic Sea. (Koźmiński and Czarnecka 1996). Within the city area, there are synanthropic plants and trees introduced by man and also primeval forest. The green areas of the city also include numerous parks, lawns and home gardens.

As a result of spatial development of the city, several types of districts have appeared. The city centre is occupied by tall buildings with rented flats, characteristic of the late nineteenth and early twentieth century. Only the northern part of the city centre is dominated by old villas. The majority of districts are covered with villas or low houses and also with blocks of flats (Koźmińska and Wojciechowska 2001).

\subsection{Methods of aerobiological investigation and Poaceae pollen data}

Analysis of the pollen count distribution was performed on the basis of the data collected in Szczecin in the seasons of 2004-2008. The volumetric measurement point was located on the roof of the University building (University of Szczecin, Faculty of Natural Science) in the centre of the city of Szczecin $\left(53^{\circ} 26^{\prime} 26^{\prime \prime} \mathrm{N}, 14^{\circ} 32^{\prime} 50^{\prime \prime} \mathrm{E}\right)$, at an elevation of $21 \mathrm{~m}$ above ground level, $52 \mathrm{~m}$ above sea level (the roof). The measuring site was in direct vicinity $0.5 \mathrm{~km}$ north-west from the Jan Kasprowicz Park, the largest green complex in the part of Szczecin on the left bank of the Odra River. In the flora of Szczecin city to the most frequently from among genera in the Poaceae family belong: Poa, Calamagrostis, Lolium, Bromus, Agropyron, Dactylis, Phleum, Alopecurus, Arrhenatherum, Secale, Avena, Triticum, Deschampsia, Briza, Holcus (Ćwikliński 1970). The pollen count was measured by the Hirst-type volumetric spore trap (Lanzoni VPPS-2000, Italy). A microscopic slide was made for each day of measurements. Pollen grains were counted along 4 longitudinal transects, which were divided into 2-mm (1 hourly) intervals; the pollen concentration was expressed as the 24-h average number of pollen grains $/ \mathrm{m}^{3}$.

Pollen grains of grass were classed in the family Poaceae with the exception of Secale genus which was studied separately.

On the basis of literature data, the number of days with the pollen count of the Secale genus and the other grass taxa, exceeding the threshold values at which the consecutive allergy symptoms develop, was determined and is given in Table 1. Rapiejko et al. (2004) reported the threshold values of grass pollen concentrations with the corresponding clinical symptoms. Hofman and Michalik (1998) and Rudzki (1998) specified the threshold value for first symptoms of rye pollen allergy in Poland. The differences between the number of grains which can evoke the first symptoms of pollinosis in Polish patients sensitive to grass pollen in general $\left(20\right.$ grains $\left./ \mathrm{m}^{3}\right)$ and to Secale pollen allergens (10 grains $\left./ \mathrm{m}^{3}\right)$ implied the necessity of separate analysis of these taxa.

\subsection{Methods in the verification of results}

The pollen season (PS) in particular years was counted as the period from which the sum of daily mean pollen concentration reaches $1 \%$ of the total sum, until the time when the sum reaches $99 \%$, i.e. the time with $98 \%$ of the whole pollen amount $(98 \%$ method) (Emberlin et al. 1993; Galán et al. 1995). 
Table 1 Characteristics of the pollen seasons PS ( $98 \%$ total sum of pollen concentration) and number of days with pollen count over an allergenic significantly value: days $>20$ grains $/ \mathrm{m}^{3}$ - first symptoms (Rapiejko et al. 2004)

\begin{tabular}{llllllll}
\hline Feature of pollen season & 2004 & 2005 & 2006 & 2007 & 2008 & $\begin{array}{l}\text { Mean values SD } \\
\text { 2004-2008 }\end{array}$ \\
& & & & & \\
Poaceae (except Secale cereale) & & & & & \\
PS & $18 \mathrm{~V}-12 \mathrm{X}$ & $22 \mathrm{~V}-10 \mathrm{IX}$ & $23 \mathrm{~V}-24 \mathrm{IX}$ & $6 \mathrm{~V}-14 \mathrm{IX}$ & $20 \mathrm{~V}-9 \mathrm{IX}$ & $18 \mathrm{~V}-20 \mathrm{IX}$ & $11 \mathrm{~V} \div 25 \mathrm{~V}-6 \mathrm{IX} \div 4 \mathrm{X}$ \\
Length & 148 & 113 & 125 & 132 & 112 & 126.0 & 14.9 \\
Max/date & $171 / 8 \mathrm{VII}$ & $183 / 18 \mathrm{VI}$ & $196 / 1 \mathrm{VII}$ & $435 / 10 \mathrm{VI}$ & $233 / 8 \mathrm{VI}$ & $243.6 / 21 \mathrm{VI}$ & $109.5 / 8 \mathrm{VI} \div 4 \mathrm{VII}$ \\
Total pollen & 4370 & 4618 & 3526 & 5112 & 4022 & 4329.6 & 599.4 \\
Days $>20$ grains $/ \mathrm{m}^{3}$ & 72 & 51 & 47 & 57 & 50 & 55.4 & 10.0 \\
Skewness & 2.00 & 1.64 & 2.10 & 3.50 & 2.36 & 2.320 & - \\
Secale cereale & & & & & & & \\
PS & $22 \mathrm{~V}-15 \mathrm{VI}$ & $18 \mathrm{~V}-29 \mathrm{VI}$ & $23 \mathrm{~V}-5 \mathrm{VII}$ & $14 \mathrm{~V}-14 \mathrm{VI}$ & $22 \mathrm{~V}-19 \mathrm{VI}$ & $20 \mathrm{~V}-22 \mathrm{VI}$ & $16 \mathrm{~V} \div 24 \mathrm{~V}-11 \mathrm{VI} \div 1 \mathrm{VII}$ \\
Length & 25 & 43 & 45 & 32 & 28 & 34.6 & 9.0 \\
Max/date & $21 / 1 \mathrm{VI}$ & $23 / 4 \mathrm{VI}$ & $21 / 15 \mathrm{VI}$ & $22 / 21 \mathrm{~V}$ & $25 / 30 \mathrm{~V}$ & $22.4 / 2 \mathrm{VI}$ & $1.7 / 24 \mathrm{~V} \div 11 \mathrm{VI}$ \\
Total pollen & 150 & 205 & 158 & 166 & 167 & 169.2 & 21.2 \\
Days $>10$ grains $/ \mathrm{m}^{3}$ & 6 & 6 & 4 & 6 & 6 & 5.6 & 0.9 \\
Skewness & 1.74 & 2.35 & 2.47 & 2.2 & 1.83 & 2.080 & -
\end{tabular}

The number of days with rye pollen over a threshold value at which the first symptoms develop: days $>10$ grains $/ \mathrm{m}^{3}$ (Hofman and Michalik 1998; Rudzki 1998)

$S D$ standard deviation

The period over which the threat related to the grass pollen presence is the greatest in the air, i.e. the main pollen season, was established as proposed by Nilsson and Persson (1981) as the period from which the sum of daily mean count concentrations reached $5 \%$ of the total sum until the time when the sum achieved $95 \%$ of the total sum. To describe the main features of the pollen season, the stages at which the cumulative pollen sum reaches the values of $1-2.5 \%$, $2.5-5 \%, 5-25 \%, 25-50 \%, 50 \%, 50-75 \%, 75-95 \%$, 95-97.5\% and $97.5-99 \%$ of the total annual pollen count are illustrated in Figs. 1 and 2. The progress of the pollen season was presented according to the method described by Latałowa et al. (2002).
Fig. 1 Dynamics of Poaceae pollen seasons in Szczecin, 2004-2008; following stages of the pollen season: (1) starts at the date for $1 \%$, (2) $2.5-5 \%$, (3) $5-25 \%$, (4) $25-50 \%,(5)$ $50 \%$ (vertical line), (6) $50-75 \%$, (7) 75-95\%, (8) 95-97.5\% (9) ends at the date for $99 \%$ of the annual pollen sum. Filled inverted triangle date of maximum pollen count
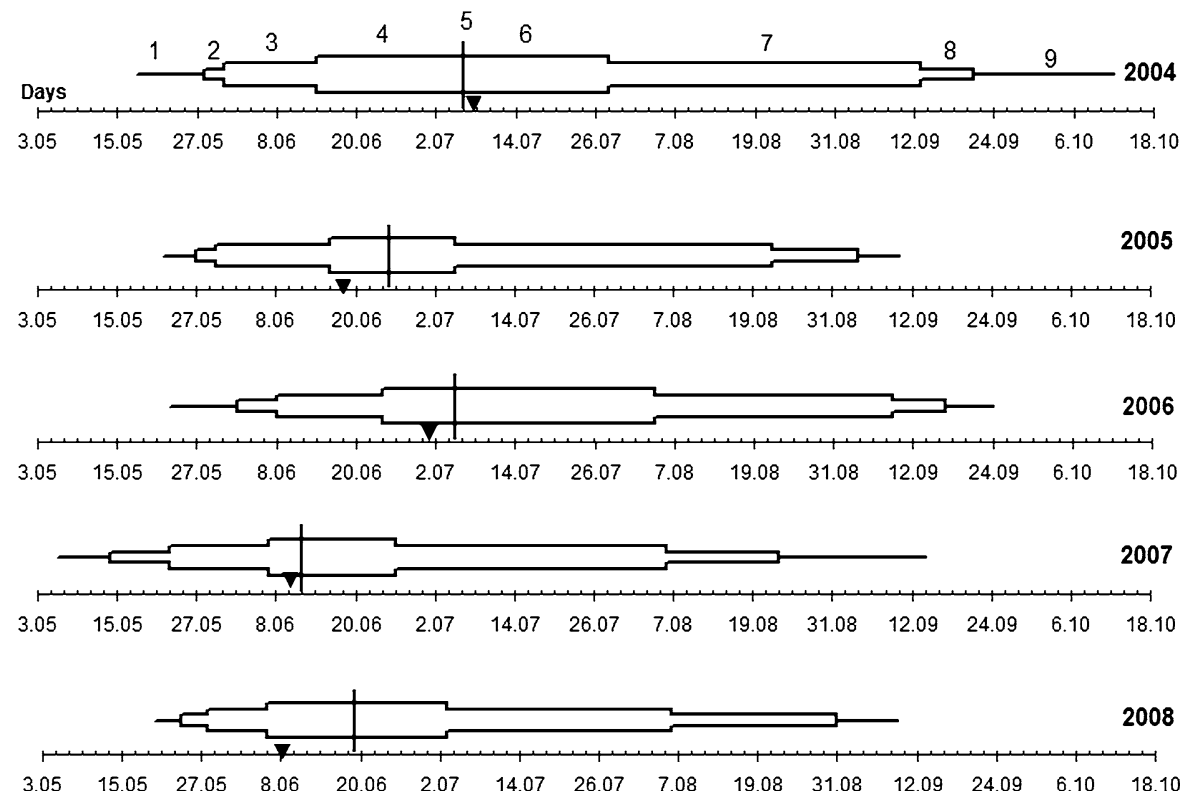
Fig. 2 Dynamics of Secale pollen seasons in Szczecin, 2004-2008; following stages of the pollen season: (1) starts at the date for $1 \%$, (2) $2.5-5 \%$, (3) $5-25 \%$, (4) $25-50 \%$, (5) $50 \%$ (vertical line), (6) 50-75\%, (7) 75-95\%, (8) 95-97.5\% (9) ends at the date for $99 \%$ of the annual pollen sum. Filled inverted triangle date of maximum pollen count
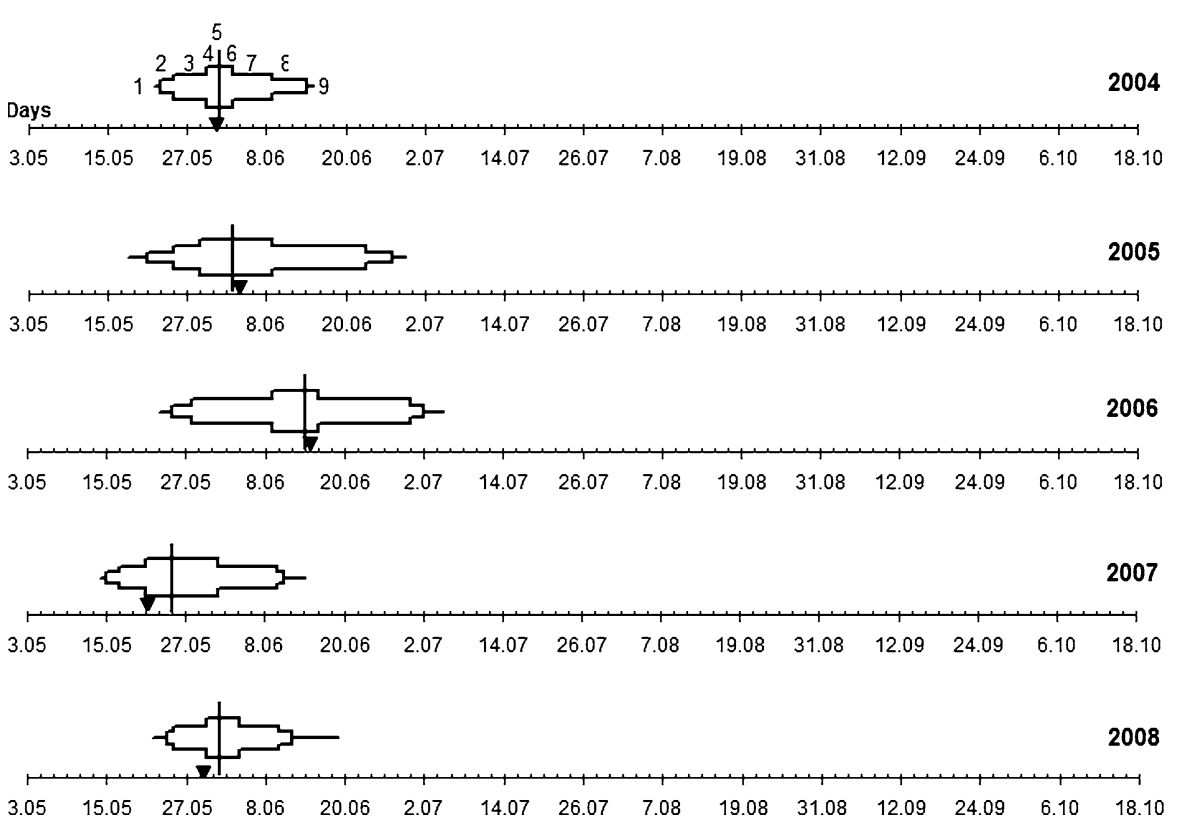

Variation in the season features analysed in Table 1 was evaluated on the basis of the standard deviation (SD) and skewness (the degree of asymmetry of a given distribution about the mean value).

The meteorological daily average data for the 5 years and daily average air pollution data for 4 years (the data for 2004 are missing) were provided by the Automatic Weather Station (Vaisala MAWS101, Helsinki, Finland), placed right next to volumetric sampler. The meteorological factors taken into regard in assessment of the effect of meteorological conditions on the airborne pollen were maximum wind speed, amount of precipitation, relative humidity, mean and maximum air temperature, and the dew point, according to literature data (Peternel et al. 2006; Kasprzyk 2008; Jato et al. 2009; Kasprzyk and Walanus 2010). The air pollution data $\left(\mu \mathrm{g} / \mathrm{m}^{3}\right)$ analysed were the concentrations of ozone, sulphur dioxide, nitrogen oxides and particulate matter $\left(\mathrm{PM}_{10}\right)$. The degrees of correlation between particular meteorological and air pollution factors, and the concentration of grass pollen were described by the Spearman's rank correlation coefficient due to the presence of non-normality and non-linearity in the data set. Further, pollen counts were $\log (x+1)$ transformed in order to normalize their distributions and linearize their dependences on meteorological parameters and pollution. Then, the multiple regression analysis was applied using Statistica software version 9.0 (StatSoft Inc 2008). Statistical error risk was estimated at the significance level of $95 \%$, $\alpha \leq 0.05$. Multiple regression was performed to understand the combined influence of meteorological variables and air pollution on airborne pollen and assess predictive performance of such models.

\section{Results}

As the family Poaceae is represented by many taxa, the pollen seasons were very long, whereas the analysis of one Secale genus showed short, compact seasons with very brief particular phases. The length of the Poaceae pollen season varied considerably from 112 days in 2008 and 2006 (113 days) to 148 days in 2004. The pollen of ryegrass occurred in the air from 25 to 45 days; the shortest pollen season was observed in 2004 and the longest period in 2006 (Table 1; Figs. 1, 2). From among the five Poaceae pollen periods analysed, the lowest peak value of 171 grains $/ \mathrm{m}^{3}$ was noted in 2004 . The highest pollen concentration of 435 grains $/ \mathrm{m}^{3}$ occurred in 2007. However, the concentrations of Secale pollen grains were very similar in all years studied, and the maximum values were in the range 21-25 grains $/ \mathrm{m}^{3}$. The highest annual total sum was observed in 2005, and the lowest annual sum occurred in 2004, so in the years different from those of the maxima in the other genera of grass family (Table 1). 
The main pollen season determined by the $90 \%$ method started for grass family at the end of May and lasted to the second decade of September and for Secale genus from the second half of May in 2007 to the end of June in 2006. In this time, in the air over Szczecin, the pollen count of grass family was very high and the allergic people developed the symptoms of pollinosis (Rapiejko et al. 2004). The period, in which the grass pollen count exceeded the threshold value of 20 grains $/ \mathrm{m}^{3}$ causing the first symptoms, lasted in Szczecin from 47 to 72 days. (Fig. 1; Table 1). The flowering and pollination of ryegrass take place in Poland usually from the half of May to the half of June. However, in the 5 years studied, the risk of allergy to Secale pollen was observed during about a week (Fig. 2; Table 1). A separate analysis of ryegrass pollen season showed visible allergy disease threat at the beginning of the grass pollen season.

The diagrams representing the dynamics of the Poaceae pollen occurrence are long in general and asymmetric. The pollen concentration distributions in individual seasons are strongly skewed to the right (Fig. 1; Table 1). The initial phases $(1,2)$ last 5-10 days and are considerably shorter than the final ones, which indicate more intense pollination in the beginning of the season. The length of the middle phases $(25-75 \%)$ changed alternately, every second year; however, this observation needs to be confirmed by long-term studies. The dates of the maximum pollen count (Table 1, Fig. 1) were recorded before the phase of $50 \%$ total pollen sum, in subsequent years except the year 2004 .

The diagrams of dynamics of the Secale pollen season are regular, short and asymmetric except that for the year 2006 (Fig. 2). The pollen concentration distributions in particular seasons are strongly skewed to the right, similarly the whole Poaceae family (Table 1$)$. The initials stages $(1,2.5,5 \%)$ are very short, similarly as the phases with the seasonal sum of pollen from 5 to $25 \%$ (4-5 days long). In 2006 , the stage of $5-25 \%$ lasted 12 days due to the lowest air temperature $\left(15-21^{\circ} \mathrm{C}\right)$ in comparison with those of the analogous stages in the other years studied. The dates of the maximum pollen count (Table 1; Fig. 2) were noted before the phase of $50 \%$ total pollen sum except for the year 2005. Analysis of standard deviation has evidenced high variation in particular features of the Poaceae pollen season (and in the length of the pollen season of Secale). The other parameters of the pollen season of the rye show low variation (Table 1).

Spearman's correlation test was performed in order to identify the major variables likely to influence the dynamic of the pollen season (Tables 2, 3). Positive and statistically significant correlation was observed between the Poaceae pollen and the mean and maximum temperatures. Rainfall and humidity revealed significant negative correlations. As far as Secale is concerned, only humidity (negative correlation) and

Table 2 Poaceae pollen counts and selected meteorological variables in the multiple regression and Spearman's rank correlation analyses in Szczecin (2004-2008)

\begin{tabular}{|c|c|c|c|c|c|}
\hline Taxon & Variance analysis at $\alpha=0.05$ & Adjusted $R$-square & Explanatory variables & $\beta$ & Spearman coefficien \\
\hline \multirow[t]{6}{*}{ Poaceae } & $F=23.66$ & 0.18 & Wind $_{\max }$ & 0.02 & -0.03 \\
\hline & $p=0.00$ & & Rain & $0.09 *$ & $-0.18 *$ \\
\hline & & & Humidity & $-0.99 *$ & $-0.39 *$ \\
\hline & & & $T_{\text {mean }}$ & $-1.09 *$ & $0.29 *$ \\
\hline & & & $T_{\max }$ & $0.37 *$ & $0.35^{*}$ \\
\hline & & & Dew point & $0.79 *$ & -0.01 \\
\hline \multirow[t]{6}{*}{ Secale } & $F=2.92$ & 0.06 & Wind $_{\max }$ & 0.06 & 0.02 \\
\hline & $p=0.01$ & & Rain & 0.02 & -0.14 \\
\hline & & & Humidity & 0.85 & $-0.19^{*}$ \\
\hline & & & $T_{\text {mean }}$ & 0.78 & 0.12 \\
\hline & & & $T_{\max }$ & $0.65 *$ & $0.16^{*}$ \\
\hline & & & Dew point & -1.22 & -0.06 \\
\hline
\end{tabular}

* Statistical significance $p<0.05$ 
maximum temperature (positive correlation) significantly influenced the pollen counts.

Analysis of relationships between the pollen counts and the air pollution showed positive correlations with ozone and $\mathrm{PM}_{10}$ contents (Poaceae and Secale) as well as with $\mathrm{SO}_{2}$ content (only Poaceae).

Spearman's rank correlation analysis between meteorological factors and pollutants showed some significant relationships but of rather low strength (Table 4).

The multiple regression analysis was performed in order to determine how much of total variance in pollen counts can be explained by meteorological variables (Table 2), air pollution (Table 3 ) and all the other factors (Table 5). For Poaceae, meteorological parameters explained $18 \%$ of the total variance. All the variables were important in the model except for the maximum wind speed. Higher portion of variance
(23\%) was explained by the effect of pollutants $\left(\mathrm{O}_{3}, \mathrm{SO}_{2}, \mathrm{PM}_{10}\right)$. The multiple regression models between Secale and meteorological conditions and pollutants exhibited even lower predictive abilities; they explained 6 and $8 \%$ of the total variance, respectively. Only maximum temperature, ozone and $\mathrm{PM}_{10}$ were important in the models. The model with both sets of environmental parameters explained $27 \%$ of total variance for Poaceae (significant explanatory variables: rain, $\mathrm{SO}_{2}, \mathrm{O}_{3}, \mathrm{PM}_{10}$ ) and $13 \%$ of Secale pollen count variance (explanatory variableshumidity, dew point temperature, $\mathrm{PM}_{10}$ ).

\section{Discussion and conclusion}

In the Polish population, patients suffering from pollinosis are most frequently allergic to wild grasses
Table 3 Poaceae pollen counts and selected air pollution in the multiple regression analysis and Spearman coefficient in Szczecin (2005-2008) (lack of the air pollution data in 2004)

* Statistical significance $p<0.05$

\begin{tabular}{|c|c|c|c|c|c|}
\hline Taxon & $\begin{array}{l}\text { Variance analysis } \\
\text { at } \alpha=0.05\end{array}$ & $\begin{array}{l}\text { Adjusted } \\
R \text {-square }\end{array}$ & $\begin{array}{l}\text { Explanatory } \\
\text { variables }\end{array}$ & $\beta$ & $\begin{array}{l}\text { Spearman } \\
\text { coefficient }\end{array}$ \\
\hline \multirow[t]{7}{*}{ Poaceae } & $F=19.82$ & 0.23 & $\mathrm{SO}_{2}$ & $0.26 *$ & $0.12 *$ \\
\hline & $p=0.00$ & & NO & -0.13 & -0.05 \\
\hline & & & $\mathrm{NO}_{2}$ & -0.13 & 0.00 \\
\hline & & & $\mathrm{O}_{3}$ & $0.31 *$ & $0.46^{*}$ \\
\hline & & & $\mathrm{NO}_{\mathrm{x}}$ & 0.13 & -0.02 \\
\hline & & & $\mathrm{PM}_{10}$ & $0.18 *$ & $0.32 *$ \\
\hline & & & $\mathrm{CO}$ & -0.02 & 0.02 \\
\hline \multirow[t]{7}{*}{ Secale } & $F=2.76$ & 0.08 & $\mathrm{SO}_{2}$ & -0.13 & -0.06 \\
\hline & $p=0.01$ & & NO & -0.63 & -0.07 \\
\hline & & & $\mathrm{NO}_{2}$ & -0.77 & 0.04 \\
\hline & & & $\mathrm{O}_{3}$ & $0.23 *$ & $0.19 *$ \\
\hline & & & $\mathrm{NO}_{\mathrm{x}}$ & 1.40 & -0.00 \\
\hline & & & $\mathrm{PM}_{10}$ & $0.24 *$ & $0.18 *$ \\
\hline & & & $\mathrm{CO}$ & -0.12 & -0.07 \\
\hline
\end{tabular}

Table 4 Spearman's rank correlation analysis between meteorological variables and air pollutant concentrations in Szczecin (20052008)

\begin{tabular}{lccccccc}
\hline Factors & $\mathrm{SO}_{2}\left(\mu \mathrm{g} / \mathrm{m}^{3}\right)$ & $\mathrm{NO}\left(\mu \mathrm{g} / \mathrm{m}^{3}\right)$ & $\mathrm{NO}_{2}\left(\mu \mathrm{g} / \mathrm{m}^{3}\right)$ & $\mathrm{O}_{3}\left(\mu \mathrm{g} / \mathrm{m}^{3}\right)$ & $\mathrm{NO}_{\mathrm{x}}\left(\mu \mathrm{g} / \mathrm{m}^{3}\right)$ & $\mathrm{PM}_{10}\left(\mu \mathrm{g} / \mathrm{m}^{3}\right)$ & $\mathrm{CO}\left(\mu \mathrm{g} / \mathrm{m}^{3}\right)$ \\
\hline Wind $_{\text {max }}(\mathrm{m} / \mathrm{s})$ & 0.05 & 0.02 & -0.02 & $0.33^{*}$ & -0.01 & $-0.18^{*}$ & $-0.26^{*}$ \\
Rain $(\mathrm{mm})$ & $-0.26^{*}$ & $-0.24^{*}$ & $-0.25^{*}$ & -0.13 & $-0.25^{*}$ & $-0.24^{*}$ & 0.04 \\
Humidity $(\%)$ & $-0.39^{*}$ & $-0.33^{*}$ & $-0.31^{*}$ & $-0.32^{*}$ & $-0.32^{*}$ & -0.13 & $0.19^{*}$ \\
$T_{\text {mean }}\left({ }^{\circ} \mathrm{C}\right)$ & $0.18^{*}$ & 0.01 & 0.13 & $0.20^{*}$ & 0.08 & $0.54^{*}$ & 0.08 \\
$T_{\text {max }}\left({ }^{\circ} \mathrm{C}\right)$ & $0.21^{*}$ & 0.05 & $0.20^{*}$ & $0.19^{*}$ & 0.14 & $0.52^{*}$ & 0.08 \\
Dew point $\left({ }^{\circ} \mathrm{C}\right)$ & $-0.18^{*}$ & $-0.27^{*}$ & -0.12 & -0.12 & $-0.18^{*}$ & $0.50^{*}$ & $0.26^{*}$ \\
\hline
\end{tabular}

* Significant coefficients, $p<0.05$ 
Table 5 Poaceae pollen counts, selected air pollution and meteorological variables in the multiple regression analysis in Szczecin (2005-2008) (lack of the air pollution data in 2004)

\begin{tabular}{llllr}
\hline Taxon & $\begin{array}{l}\text { Variance analysis } \\
\text { at } \alpha=0.05\end{array}$ & $\begin{array}{l}\text { Adjusted } \\
R \text {-square }\end{array}$ & $\begin{array}{l}\text { Significant explanatory } \\
\text { variables } p<0.05\end{array}$ & $\beta$ \\
\hline Poaceae & $F=13.18$ & 0.27 & Rain & 0.09 \\
& $p=0.00$ & & $\mathrm{SO}_{2}$ & 0.22 \\
& & $\mathrm{O}_{3}$ & 0.21 \\
& & & $\mathrm{PM}_{10}$ & 0.14 \\
Secale & \multirow{2}{*}{0.13} & Humidity & 1.46 \\
& $p=0.00$ & & Dew point & -1.86 \\
& & & $\mathrm{PM}_{10}$ & 0.28 \\
\hline
\end{tabular}

and rye pollens (Jahnz-Różyk et al. 2001). Because of the large number of Poaceae species, the pollen season of grasses is very long and in Central Europe lasts for over 5 months. The Poaceae pollen is present abundantly over most of the area of Poland from the half of May to the half of August (Piotrowska and Weryszko-Chmielewska 2003; Szczepanek 1994). The grass pollen season in Szczecin lasts for about 5 months, and the highest Poaceae pollen count is recorded from the end of May to the half of September.

The dates of the beginning of the pollen seasons of grasses observed in subsequent years were different. The differences were accounted for by the meteorological conditions, especially the air temperature in the spring and the amount of precipitation in the period before pollen season (Sánchez-Mesa et al. 2003). In Szczecin, the grass pollen season starts usually in the second decade of May; however, the differences in the dates in subsequent years reach over a dozen days. A remarkable difference between the earliest and the latest onset of pollen season, of as many as 63 days, was recorded in Vigo, Spain (Jato et al. 2009). Garcia-Mozo et al. (2009) reported great yearly variation in the start of main pollen season of a Poaceae compared with the peak day, because early flowering grass species like Dactylis glomerata (orchad grass) are most responsive to meteorological conditions. In Szczecin, the diagrams representing the dynamics of the Poaceae pollen season are asymmetric, and the pollen concentration distributions during pollen seasons are strongly skewed to the right. The high variation in particular features of the Poaceae pollen season is probably caused by a huge pollen productivity and the large number of species included in this family. The initial phases (1-3) are considerably shorter than the final ones and indicate more intense pollination in the beginning of the season. It could be a result of the high air temperature of above $22^{\circ} \mathrm{C}$, which induces almost total emptying of grass anthers in 2-3 days. The blossoming period of a single flower of Secale cereale lasts 14-60 min, while that of a ear reaches about 5 days (Tarkowski 1983), which in the diagrams of the seasonal dynamics is manifested as a shortening of the initial stages of pollen season. The extension of final stages is a result of the second fall of grass pollen (resuspension) and medium- and long-distance transport of pollen (Szczepanek 1994; Helbig et al. 2004; Jato et al. 2006).

Air pollution can aggravate the symptoms of pollinosis. Taylor et al. (2002) have shown that synergistic combination of allergen-loaded pollen debris and aromatic hydrocarbons, found in fine combustion aerosols, might explain the increased prevalence of pollen-induced asthma in the last half century. Motta et al. (2006) have reported that trafficrelated pollutants $\left(\mathrm{NO}_{2}, \mathrm{O}_{3}\right)$ can trigger the release of allergen-containing granules from grass pollen and increase the bioavailability of airborne pollen allergens. In Szczecin, a co-occurrence was recorded between Poaceae pollen count and the concentration of $\mathrm{SO}_{2}, \mathrm{O}_{3}$ and $\mathrm{PM}_{10}$ in the multiple regression as well as Spearman's rank correlation analysis. The regression models can be used for predicting the levels and interrelationship between pollen count, other pollutants and meteorological conditions. The particulate air pollution is associated with increased respiratory morbidity and mortality, and these effects are exacerbated in persons with pre-existing inflammatory lung disease (González-Flecha 2004). Ornstad et al. (1998) reported that the particulate matter $\left(\mathrm{PM}_{10}\right)$ consisted predominantly of carbon aggregates of which the majority were smaller than $1 \mu \mathrm{m}$, and 
these particles have important allergens attached to their surface. Feo Brito et al. (2007) confirmed that pollen-allergic asthmatic patients living in a more polluted region present more symptoms of seasonal asthma than those living in a city with low level of pollution. In Cincinnati, Ohio, USA, positive Spearman's correlation was found between $\mathrm{PM}_{10}$, ozone concentration and Poaceae pollen count. However, the linear regression models for the pairs of variables showed statistically significant correlations between air temperature, and ozone and $\mathrm{PM}_{10}$ levels (Adhikari et al. 2006). The weather conditions (independent variables) influence pollen and pollution concentrations (dependent variables); however, air pollution does not influence pollen counts; nevertheless, these variables occurred in the same time. The results obtained in Szczecin in the multiple regression analysis have also shown that the pollen count of grass is positively correlated with the concentration of $\mathrm{O}_{3}$ and particulate matter concentration as a result of the atmospheric temperature influence. The elevated air temperature is a result of high insolation, favouring photochemical reactions between nitrogen oxides and hydrocarbons (main emission sources: diesel exhaust and industry) leading to formation of ozone (Roberts 1990). The elevated content of ozone and pollen in the atmospheric air was recorded on warm sunny days during the pollen season (also in Szczecin).

The meteorological conditions belong to important factors affecting the airborne pollen count. In Szczecin, the correlations between the pollen content in the air and the mean and maximum day temperature, amount of precipitation and relative humidity were found. Poaceae development is strongly influenced by both temperature and rainfall, and water availability is a major determinant of growth. The positive associations between Poaceae pollen concentration and temperature are consistent with a number of previous studies (Bartkovǎ-Ščevkovă 2003; Jato et al. 2002; Stennett and Beggs 2004; Peternel et al. 2006). In Szczecin, a synchronization of occurrence was found between the grass pollen count and mean and maximum air temperature. In Rzeszów (Poland), maximum and mean temperatures were the primary factors determining the onset of Poaceae pollen season; however, the correlations were negative (Kasprzyk and Walanus 2010). Sánchez-Mesa et al. (2005) have shown that the minimum temperature was the most important factor in the city of Cordoba, whereas in other cities with a different climate, such as London, the most important factor was the maximum temperature (Galán et al. 1995). In Greece, the results of regression analysis (for the 15-year period) revealed also the significant and positive correlation between the average total pollen concentrations and average temperature values (Gioulekas et al. 2004).

Rainfall and relative humidity were found to be negatively correlated with Poaceae pollen in Szczecin. Similar results have been obtained in other cities by, for example, Bartkovǎ-Ščevkovă (2003), SánchezMesa et al. (2003), Piotrowska and WeryszkoChmielewska (2003), Rodriguez-Rajo et al. (2003), Docampo et al. (2007). Increasing grass pollen count in the air with decreasing relative humidity has been noted, for example, by Stennett and Beggs (2004), Vega-Maray et al. (2003), Peternel et al. (2006). Stennett and Beggs found little association between grass pollen and rainfall in Sydney; however, a strong positive correlation with rainfall was recorded in Spain (Jato et al. 2009). An increase in the relative air humidity is usually related to a decrease in the pollen count in the atmosphere. In these conditions, grass pollen grains often break, and the cytoplasmatic mass with the allergenic proteins is released (Grote et al. 2001). This phenomenon explains the aggravation of the allergy symptoms in the conditions of high air humidity during the pollen season of Poaceae. As the process of allergen release from the pollen grains intensifies immediately before rainfalls, at the dew point temperature, it is important to take this meteorological variable into account in the analyses of correlations with the pollen concentrations (Kasprzyk 2008).

The study conducted in Szczecin showed that there are significant correlations between various meteorological factors and air pollution and the concentration of grass pollen in the air in Szczecin. Moreover, if the relationships between a combination of several weather variables and pollen presence are tested for the same periods, the results can be different from testing individual parameters against each other, and the interactions between actual air pollution, meteorological conditions and pollen concentrations need more detailed studies. The greatest risk from Poaceae for pollen allergy sufferers in Szczecin (days $>50$ grains/ $\mathrm{m}^{3}$ ) lasts on average from mid-June to mid-August. 
However, in Galicia, Spain, an analogous period (days $>30$ grains $/ \mathrm{m}^{3}$ ) occurs from mid-May to late July, and the highest pollen count tended to be recorded in June and July (Jato et al. 2009). In Szczecin, the number of days with grass pollen count over 50 grains $/ \mathrm{m}^{3}$ was $21-32$ days per year, whereas Docampo et al. (2007) noted in Nerja (southern Spain) 11-23 days in the years 2001-2003. Maximum mean daily pollen concentration values in Catalonia, Spain, occurred in May or June, with variation between 14 and 24 days (the research concerned 5 cities in 1996-2001); however, the pollinosis risk in all years and sites reached low or medium level (Latorre and Belmonte 2004). In Zagreb, Croatia, a high variability was observed in the number of weeks when grass pollen concentration exceeded the threshold value of 30 grains $/ \mathrm{m}^{3}$, i.e. $1-5$ weeks in the years $2002-2005$ (Peternel et al. 2006). In the Porto region, Portugal, Poaceae pollen occurs mainly from April to August, with the maximum airborne concentration usually in July (Abreu et al. 2008). Garcia-Mozo et al. (2009) reported that in southern Spain, the peak date was recorded around mid-May, while at northern sites, peak pollen release was recorded in mid-June or even early June; this is the period of the highest risk of the appearance of pollinosis symptoms in persons with hypersensitivity of the grass pollen allergens.

Acknowledgments The investigation was carried out within the framework of Ministry of Science and Higher Education project No N N305 367738.

Open Access This article is distributed under the terms of the Creative Commons Attribution Noncommercial License which permits any noncommercial use, distribution, and reproduction in any medium, provided the original author(s) and source are credited.

\section{References}

Abreu, I., Ribeiro, N., Ribeiro, H., Oliveira, M., \& Cruz, A. (2008). Airborne Poaceae pollen in Porto (Portugal) and allergenic profiles of several pollen types. Aerobiologia, 24, 102-110.

Adhikari, A., Reponen, T., Grinshpun, S. A., Martuzevicius, D., \& LeMasters, G. (2006). Correlation of ambient inhalable bioaerosols with particulate matter and ozone: A two-year study. Environmental Pollution, 140, 16-128.

Andersson, K., \& Lindholm, J. (2003). Characteristic and immunobiology of grass pollen allergens. International Archives of Allergy and Immunology, 130, 87-107.
Asero, R., Mistrello, G., Roncarolo, D., D’Amato, G., Zanoni, D., Barocci, F., et al. (2003). Detection of clinical markers of sensinisation to profilin in patients allergic to plant-derived foods. Journal of Allergy and Clinical Immunology, 112, $417-423$.

Bartkovǎ-Ščevkovǎ, J. (2003). The influence of temperature, relative humidity and rainfall on the occurrence of pollen allergens (Betula, Poaceae, Ambrosia artemisifolia) in the atmosphere in Bratislava (Slovakia). International Journal of Biometeorology, 48, 1-5.

Behrend, H., \& Becker, W. M. (2001). Localization, release and bioavailability of pollen allergens: The influence of environmental factors. Current Opinion in Immunology, $13,709-715$.

Ćwikliński, E. (1970). The synanthropic flora of Szczecin. Monographiae Botanicae (pp. 89-95). Warsaw: PWN.

D’Amato, G. (1991). European airborne pollen types of allergological interest of monthly appearance of pollination in Europe. In G. D’Amato, F. Th, M. Spieksma, \& S. Bonini (Eds.), Allergenic pollen and pollinosis in Europe (pp. 66-78). Oxford: Blackwell.

D'Amato, G. (2000). Urban air pollution and plant-derived respiratory allergy. Clinical and Experimental Allergy, 30, 628-636.

D’Amato, G., Cecchi, L., Bonini, S., Nunes, C., Annesi-Maesano, I., Behrendt, H., et al. (2007). Allergenic pollen and pollen allergy in Europe. Allergy, 63, 1398-9995.

Davies, R. R., \& Smith, L. P. (1973). Forecasting the start and severity of the hay fiver season. Clinical Allergy, 3, 263-267.

De Vries, A. Ph. (1971). Flowering biology of wheat, particularly in view of hybrid seed production a review. Euphytica, 20, 152-169.

Docampo, S., Recio, M., Mar Trigo, M., Melgar, M., \& Cabezudo, B. (2007). Risk of allergy in Nerja (southern Spain): A pollen calendar. Aerobiologia, 23, 189-199.

Emberlin, J., Savage, M., \& Woodman, R. (1993). Annual variations in Betula pollen season in London 1961-1990. Grana, 32, 359-364.

Feo Brito, F., Mur Gimeno, P., Martinez, C., Tobias, A., Suarez, L., Guerra, F., et al. (2007). Air pollution and seasonal asthma during the pollen season. A cohort study in Puertollano and Ciudad Real (Spain). Allegy, 62, 1152-1157.

Galán, C., Emberlin, J., Dominguez, E., Bryant, R. H., \& Villamandos, F. (1995). A comparative analysis of daily variations in the Gramineae pollen counts at Còrdoba, Spain and London, UK. Grana, 34, 189-198.

Garcia-Mozo, H., Galán, C., Belmonte, J., Bermejo, D., Candau, P., Diaz de la Guaria, C., et al. (2009). Predicting start and peak dates of the Poaceae pollen season in Spain using process-based models. Agricultural and Forest Meteorology, 149, 256-262.

Gioulekas, D., Balafoutis, Ch., Damialis, A., Papakosta, D., Gioulekas, G., \& Patakas, D. (2004). Fifteen years' record of airborne allergenic pollen and meteorological parameters in Thessaloniki, Greece. International Journal of Biometeorology, 48, 128-136.

González-Flecha, B. (2004). Oxidant mechanisms in response to ambient air particles. Molecular Aspects of Medicine, $25,169-182$. 
Grote, M., Vrtala, S., Niederberger, V., Wiermann, R., Valenta, R., \& Reichelt, R. (2001). Release of allergen-bearing cytoplasm from hydrated pollen: A mechanism common to a variety of grass (Poaceae) species revealed by electron microscopy. Journal of Allergy and Clinical Iттиnology, 108, 109-115.

Helbig, N., Vogel, B., Vogel, H., \& Fiedler, F. (2004). Numerical modelling of pollen dispersion on the regional scale. Aerobiologia, 20, 3-19.

Hofman, T., \& Michalik, J. (1998). Alergia Pytkowa. Poznań: TOM.

Jahnz-Różyk, K., Głodzińska-Wyszogrodzka, E., Płusa, T., \& Rożyńska-Polańska, R. (2001). Clinical symptoms and skin trick tests in patients with pollinosis. Polski Merkuriusz lekarski, 10(59), 319-322.

Jato, V., Dapazo, A., \& Aira, M. J. (2002). Influence of precipitation and temperature on airborne pollen concentration in Santiago de Compostela (Spain). Grana, 41, 232-241.

Jato, V., Rodriquez-Rajo, F. J., Alcázar, P., De Nuntiis, P., Galán, C., \& Mandrioli, P. (2006). May the definition of pollen season influence aerobiological results? Aerobiologia, 22, 13-25.

Jato, V., Rodriquez-Rajo, F. J., Seijo, M. C., \& Aira, M. J. (2009). Poaceae pollen in Galicia (N. W. Spain): Characterization and recent trends in atmospheric season. International Journal of Biometeorology, 53, 333-344.

Jianan, X., Zhiyun, O., Hua, Z., Xiaoke, W., \& Hong, M. (2007). Allergrnic pollen plants and their influential factors in urban areas. Acta Ecologica Sinica, 27(9), 3820-3827.

Kasprzyk, I. (2008). Non-native Ambrosia pollen in the atmosphere of Rzeszów (SE Poland); evaluation of the effect of weather conditions on daily concentrations and starting dates of the pollen season. International Journal of Biometeorology, 52, 341-351.

Kasprzyk, I., \& Walanus, A. (2010). Description of the main Poaceae pollen season using bi-Gaussian curves, and forecasting methods for the start and peak dates for this type of season in Rzeszów and Ostrowiec Św. (SE Poland). Journal of Environmental Monitoring, 12, 906-916.

Koźmińska, B., \& Wojciechowska, D. (2001). Szczecin z daleka $i$ z bliska (pp. 60-79). Szczecin: Zapol, Muzeum Narodowe.

Koźmiński, C., \& Czarnecka, M. (1996). Klimat miasta Szczecina i okolicy. In J. Jasnowska (Ed.), Stan Środowiska Miasta i Rejonu Szczecina (pp. 49-68). Szczecin: Szczecińskie Towarzystwo Naukowe.

Latałowa, M., Miętus, M., \& Urska, A. (2002). Seasonal variations in the atmospheric Betula pollen count in Gdansk (Southern Baltic coast) in relation to meteorological parameters. Aerobiologia, 18, 33-43.

Latorre, F., \& Belmonte, J. (2004). Temporal and spatial distribution of atmospheric Poaceae pollen in Catalonia (NE Spain) in 1996-2001. Grana, 43, 156-163.

Masuch, G., Franz, J. T., Schoene, K., Müsken, H., Bergmann, K-Ch., \& Wahl, R. (1997). Einflu $\beta$ von Ozon auf den Gehalt von Gruppe 5 in Pollen und Pflanzen-bestandreilen von Lolium perenne. In 4.Europä̈sches Pollenflug-
Symposium. 28.2.-2.3. (pp. 10-11). Bad Lippspringe: Stiftung Deutscher Pollen.

Motta, A. C., Marliere, M., Peltre, G., Sterenberg, P. A., \& Lacroix, G. (2006). Traffic-related air pollutants induce the release of allergen-containing cytoplasmatic granules from grass pollen. International Archives of Allergy and $l$ Immunology, 139(4), 323-332.

Nilsson, S., \& Persson, S. (1981). Tree pollen spectra in the Stockholm region (Sweden) 1973-1980. Grana, 20, 179-182.

Obtułowicz, K. (2001). Alergologia ogólna. In K. Obtułowicz (Ed.), Alergologia Praktyczna (pp. 17-56). Kraków: PZWL.

Ornstad, H., Johansen, B. V., \& Gaarder, P. I. (1998). Airborne house dust particles and diesel exhaust particles as allergen carries. Clinical and Experimental Allergy, 28, 702-708.

Parnia, S., Brown, J. L., \& Frew, A. (2002). Role of pollutants in allergic sensitization and the development of asthma. Allergy, 57, 1111-1117.

Peternel, R., Srnec, L., Culig, J., Hrga, I., \& Hercog, P. (2006). Poaceae pollen in the atmosphere of Zagreb (Croatia), 2002-2005. Grana, 45, 130-136.

Piotrowska, K., \& Weryszko-Chmielewska, E. (2003). Pollen count of selected taxa in the atmosphere of Lublin using two monitoring methods. Annals of Agricultural and Environmental Medicine, 10, 79-85.

Prieto-Baenapablo, J. C., Hidalgo, J., Dominguez, E., \& Galan, C. (2003). Pollen production in the Poaceae family. Grana, 42, 1-7.

Rantio-Lehtimaki, A., Koivikko, A., Kupias, R., Makinen, Y., \& Pohjola, A. (1991). Significance of sampling height of airborne particles for aerobiological information. Allergy, 46, 68-76.

Rapiejko, P., Lipiec, A., Wojdas, A., \& Jurkiewicz, D. (2004). Threshold pollen concentration necessary to evoke allergic symptoms. International Review of Allergology and Clinical Immunology, 10(3), 91-94.

Reindl, J., Anliker, M. D., Karamloo, F., Vieths, S., \& Wüthrich, B. (2000). Allergy caused by ingestion of zucchini (Cucurbita pepo): Characterization of allergens and crossreactivity to pollen and other foods. Journal of Allergy and Clinical Immunology, 106, 379-385.

Riediker, M., Monn, Ch., Köller, T., Stahel, W. A., \& Wüthrich, B. (2001). Air pollutants enhance rhinoconjunctivitis symptoms in pollen-allergenic individuals. Annals of Allergy, Asthma \& Immunology, 87, 311-318.

Roberts, J. M. (1990). The atmospheric chemistry of organic nitrates. Atmospheric Environment, 24, 245-287.

Rodriguez-Rajo, F. J., Jato, V., \& Aira, J. M. (2003). Pollen content in the atmosphere of Lugo (NW Spain) with reference to meteorological factors (1999-2001). Aerobiologia, 19, 213-225.

Rogerieux, F., Godfrin, D., Sènèchal, H., Motta, A. C., Marlière, M., Peltre, G., et al. (2007). Modifications of Phleum pretense Grass Pollen Allergens following Artificial Exposure to Gaseous Air Pollutants $\left(\mathrm{O}_{3}, \mathrm{NO}_{2}, \mathrm{SO}_{2}\right)$. Allergy and Immunology, 143, 127-134.

Rudzki, E. (1998). Co Ludzi Uczula i Jak Tego Unikać. Krakow: Medycyna Praktyczna.

Sánchez-Mesa, J. A., Galán, C., \& Hervás-Martinez, C. (2005). The use of discriminant analysis and neural network to 
forecast the severity of the Poaceae pollen season in a region with a typical Mediterranean climate. International Journal of Biometeorology, 49, 355-362.

Sánchez-Mesa, J. A., Smith, M., Emberlin, J., Allitt, U., Caulton, E., \& Galán, C. (2003). Characteristic of grass pollen seasons in area of southern Spain and the United Kingdom. Aerobiologia, 19, 243-250.

Schöene, K., Franz, J.-Th., \& Masuch, G. (2004). The effect of ozone on pollen development in Lolium perenne $\mathrm{L}$. Environmental Pollution, 131, 347-354.

Śpiewak, R., Krysińska-Traczyk, E., Sitkowska, J., \& Dutkiewicz, J. (1996). Microflora of allergenic pollensA preliminary study. Annals of Agricultural and Environmental Medicine, 3, 127-130.

StatSoft Inc (2008). STATISTICA (data analysis software system), version 9.0 www.statsoft.com.

Stennett, P. J., \& Beggs, J. (2004). Pollen in the atmosphere of Sydney, Australia, and relationships with meteorological parameters. Grana, 42, 209-216.

Szczepanek, K. (1994). Pollen calendar for Cracow (South Poland) 1982-1991. Aerobiologia, 10, 65-75.
Tarkowski, C. (1983). Biologia żyta. Warsaw: Państwowe Wydawnictwo Naukowe.

Taylor, P. E., Flagan, R. C., Valenta, R., \& Glovsky, M. M. (2002). Release of allergens as respirable aerosols: A link between grass pollen and asthma. Journal of Allergy and Clinical Immunology, 57, 51-54.

Vega-Maray, A. M., Valencia-Barrera, R. M., FernándezGonzález, D., \& Fraile, R. (2003). Urticaceae pollen concentration in the atmosphere of north-western Spain. Annals of Agricultural and Environmental Medicine, 10, 249-255.

Wilson, A. M., Salloway, J. C., Wake, C. P., \& Kelly, T. (2004). Air pollution and the demand for hospital services: A review. Environment International, 30, 1109-1118.

Yanagisawa, R., Takano, H., Inoue, T.-I., Ichinose, T., Sadakane, K., Yoshino, S., et al. (2006). Components of diesel exhaust particles differentially affect $\mathrm{Th} 1 / \mathrm{Th} 2$ response in a murine model of allergic airway inflammation. Clinical and Experimental Allergy, 36, 386-395. 